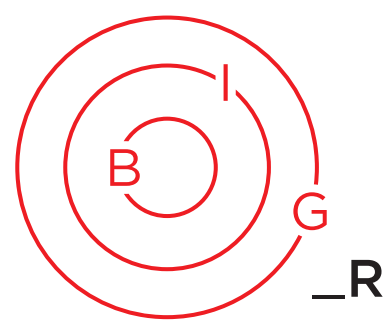

ESSAY

SPECIAL ISSUE

\title{
The Danish-German Border in Times of COVID-19
}

\author{
Martin Klatt *
}

The Danish-German border in the Schleswig region was drawn in 1920. It separated a hitherto economically and socially integrated region, taking into account the right of national self-determination. Since the late 20th century, Danish and German stakeholders have celebrated a narrative of overcoming the border. Thus, it came as a shock to local stakeholders when the border was closed in mid-March 2020 to contain the spread of the COVID-19 virus. The border subsequently reopened in steps with more or less free travel in the summer. Since October, however, new restrictions were imposed as infection numbers began rising in both countries.

\section{Introduction}

Denmark was one of the first countries in Europe to react to COVID-19 with a lockdown from 14 March 2020, including the closures of all its national borders. Germany followed two days later, but closed borders selectively: land borders to adjoining Belgium, Luxembourg, France, Switzerland and Austria were closed, as was air travel from Spain, France and Italy. Germany's land border points of entry from the Netherlands, Poland, the Czech Republic, Sweden (ferry), Finland (ferry) and Lithuania (ferry) remained open in principle, as did air travel within the Schengen zone; but travel

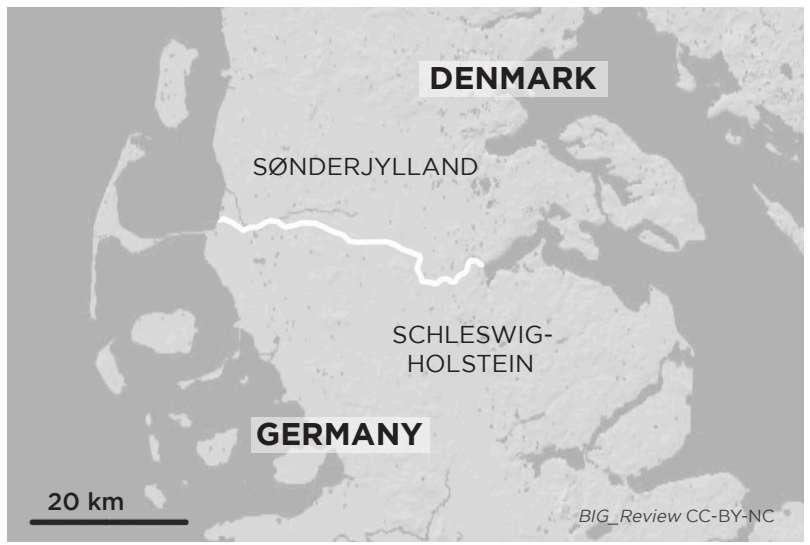

limitations existed as Poland, Lithuania, Finland and the Czech Republic had closed their borders for inbound travel. In fact, only the German-Dutch border remained uncontrolled during the COVID-19 crisis; but there was a travel warning.

This paper will briefly explain the situation at the DanishGerman border before COVID-19, the situation during the lockdown and the gradual re-opening process. ${ }^{1}$

\section{The Danish-German Border: A Schengen Euroregion}

The European Union (EU) Schengen system of open borders for free movement of people within Europe was implemented at the Danish-German border in March 2001. This included the destruction of control buildings, as well as the opening of minor road crossings as well as bike and pedestrian trails. There was even set up a special cross-border bike trail, the Grenzroute/grænserute, co-funded with the EU's program for cross-border cooperation, Interreg. Hence, customs or police control only occurred on a random basis, and not immediately at the border crossing points. In early summer 2011, the right-liberal Danish government reintroduced 24/7 custom

\footnotetext{
* Martin Klatt, PhD, Centre for Border Region Studies, University of Southern Denmark. Email: mk@sam.sdu.dk Twitter: @klatt_mk
} 
controls at the border in a domestic political trade-off to get parliamentary support for a pension reform. This move was renounced a few months later after a shift of government and pressure from the EU, Germany and regional political stakeholders (Wind 2012). During the so-called migration crisis of autumn 2015, though, the issue of renewed controls came on the agenda again. In January 2016, Denmark, in line with Sweden, Germany and Austria, introduced border controls for northbound travel. These controls functioned within the Schengen agreement's provision to enact temporary border controls in case of events that threaten law and order. The controls were renewed about every two months, since June 2017 with the argument of the continuous threat of terror. In practice, these controls were at random. Only three of the 17 road crossings were manned 24/7, and vehicles were taken out for inspection on specific profiles only, especially people driving cars registered with Central and Eastern European license plates, and Middle Eastern looking persons had a higher risk of being asked to show travel documents (Klatt 2020). When the African swine fever approached central Europe with the first cases detected in Poland, Denmark decided to construct a fence along the land border to Germany to prevent wild boars from entering the country in late 2018. Even though the usefulness of the fence was debated among experts, construction finished in November 2019. The wild boar fence is the first fencing of the Danish-German border ever, except for provisional fences erected immediately after World War II.

\section{The Border After the COVID-19 Closure}

The border closure was announced by the Danish government on Friday, 13 March, in the evening, only a few hours after the Danish foreign minister had affirmed that Denmark would not close her borders. This year is the border's 100th anniversary: it was drawn in 1920 to solve a conflict on the region's national belonging to a Danish or German nation state. The exact line of the border was confirmed in two internationally supervised plebiscites, so it is one of the few borders in the world the people voted on (Fink 1979). The 2020 centennial was supposed to be a year of celebration: of the reunification of the northern part of the Schleswig region with Denmark, but also reconciliation with Germany and accommodation of national conflict into a system of national minorities with cultural autonomy (Danes in northern Germany, Germans in southern Denmark) which made claims for border revision unnecessary. Ironically the celebrations carried a narrative of overcoming of the border in daily life. The sudden closure came as a shock to the mayor of Germany's border city Flensburg, who criticized the decision both on a practical basis (the virus was already in Denmark, therefore isolating infected people seemed a more appropriate response) and an emotional basis (the ideal of Europe without borders was put on ice, and the 100th anniversary celebrations had lost their meaning). The mayor was supported by the German state Schleswig-Holstein's government expressing surprise and disappointment. Several stakeholders criticized the border closure, especially the two national minorities used a narrative of a lifeline being cut, accentuated by the unfortunate coincidence of the border's 100th anniversary.

In effect, Germany followed quickly two days later and closed the border for most entries from Denmark effective 16 March. Out of the 17 crossings, only three road crossings, two rail lines (with reduced service) and two ferry crossings remained open. The closed crossings were barred with concrete blocks and mobile road bars. Controls have been rather rigorous with travelers being asked to document the purpose of their visit. On the Danish side, the crossing points are (still) staffed with police and volunteers from Hjemmeværnet (the home-guard militia); in effect the volunteers take a six-months furlough from their regular jobs and receive fully paid work contracts with the Danish Ministry of Justice. On the German side, the federal police Bundespolizei manned mobile border control posts. These were removed from 11 June, except for the international main line trains, which are still checked on arrival at the German train station in Flensburg.

The border closure was never total: commuters, goods and the persons transporting them, health service staff and children of separated parents were permitted to cross the border at any time, if they provided documentation. The German state of Schleswig-Holstein imposed a 14-day quarantine on any person entering the country who had been away for more than 48 hours, or five days in case of commuters. From mid-April, Denmark eased access to include parents visiting children and vice versa, as well as couples in a long-standing relationship, meaning having resided together. From 18 May, Germany allowed extended family visits (children, grandparents, siblings, in-laws; all only in case of important family events). At the same time, quarantine rules were dropped for people entering from EU and European Economic Area (EEA) countries as well as from the United Kingdom (UK). From 11 June, there have been no more entry restrictions to Germany for residents of EU, EEA and the UK, but quarantine rules still apply for entries from COVID-19 risk regions according to the daily updated Robert Koch Institute's list (more than 50 new infections per 100,000 inhabitants within a week). From 15 June, Denmark allowed tourists from Germany, Iceland and Norway to enter if they can document a hotel/campground/summer cottage booking of at least six nights; residents of the neighboring German state of Schleswig-Holstein have a waiver of this rule and may enter Denmark at any time. There is now a mobile COVID-19 test station on the Danish side of the border manned by Region South Denmark health services staff. By September, all small border crossings reopened and border controls entering Denmark have been reduced to pre-lockdown level. 
The 100th anniversary celebrations have become a sacrifice to the coronavirus crisis. The festivities were to start with a one-day historical conference in the Danish parliament, followed by music performance and a reception in the Danish Royal Theatre. A wide range of cultural, scientific and political events had been planned, many in a cross-border perspective. The climax was a planned visit of Queen Margrethe in June, with a reenactment of King Christian X's ride across the pre-1920 border on a white horse. All these events were cancelled or moved to spring 2021, in the hope that the virus will be under control by then. This setback for the multinational and cross-border celebration of the centennial year has a high symbolic impact, the consequences of which cannot be known, yet.

The border closure has increased awareness of crossborder flows and social interaction. The euroregional office Infocenter was suddenly confronted with many issues. On social media, people have exchanged advice on how to deal with issues caused by the border closure in different Facebook groups. ${ }^{2}$ Especially the two national minorities were active agents pressuring to reopen the border. They appealed to the necessity of cross-border cultural and personal contacts and the low infection rate in the border region. However, regional institutional cooperation has come to a total standstill.

In effect, cases affecting border region residents present a variety of disrupted cross-border living practices, not only relevant to the national minorities residing in the region: people in the process of moving into the other country, house construction on the other side of the border, child custody issues, living together with a partner who had not registered his/her address, acute family crisis/separation, and also simple issues as access to farmland, a riding horse, a sailboat or machines stored on the other side of the border. The local tourism industry and cross-border shopping centers have suffered. With the reopening, though, there are indications that border crossing practices are in the process of returning to pre-COVID-19 levels. This is partly due to the COVID-19 restrictions Denmark had imposed on her citizens' foreign travel until the beginning of July, when only travel to Germany, Norway and Iceland was allowed. In
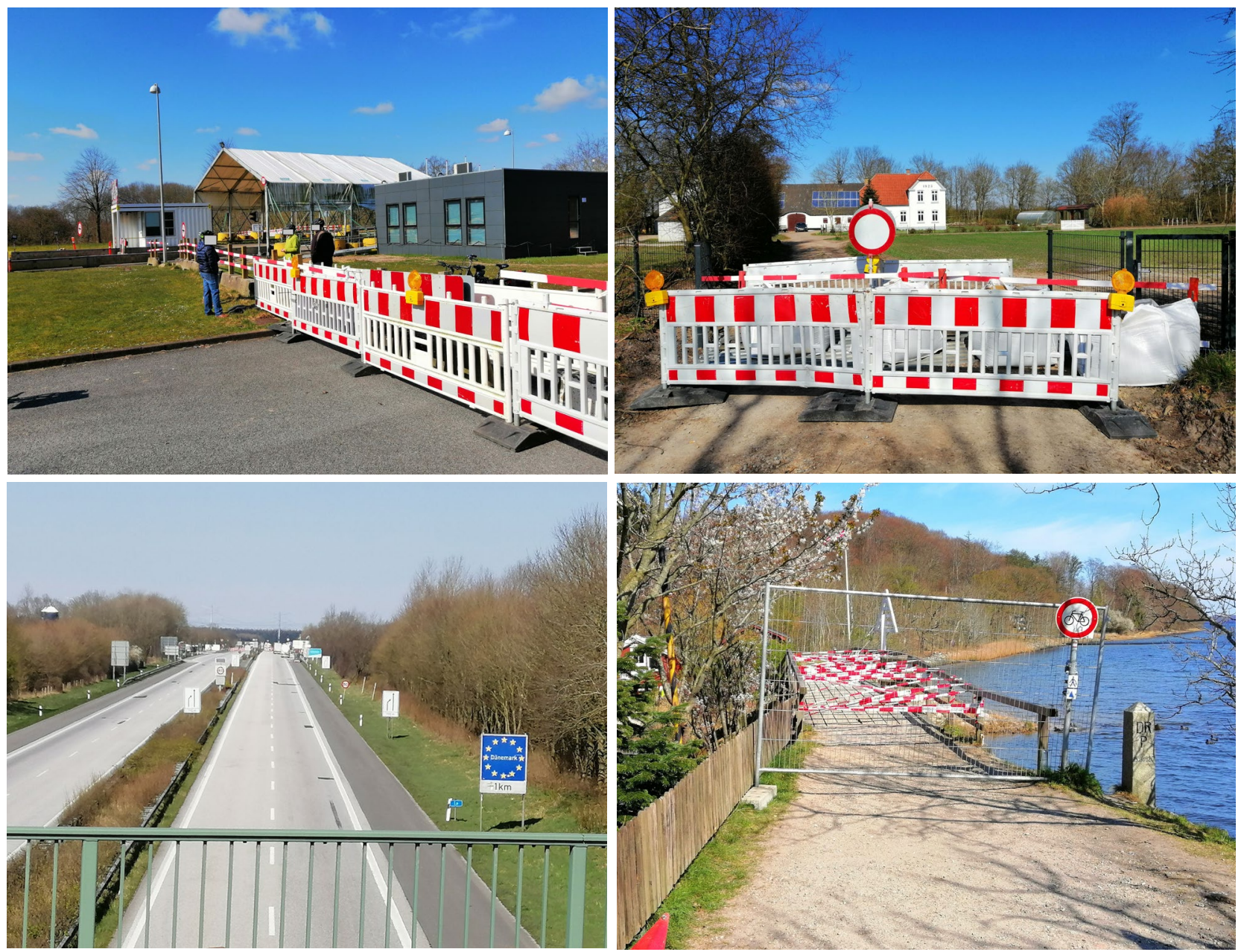

Figure 1. Closed border crossings between Denmark and Germany, late March, 2020. Photo credit: M. Klatt. 
consequence, many Danes stayed within the country during the summer instead of travelling to Southern European or overseas destinations.

\section{Conclusions: Renaissance of the Executive}

The state's return as the central single actor during the COVID-19 crisis has probably had more impact in border regions than elsewhere. Here, it has replaced formal and informal practices of cross-border multilevel governance. Measures were taken from a state-centered perspective, regarding the state as a bordered container. This implies the exceptions allowed for border crossings during the first weeks of closure: they were all seen in a critical infrastructure framework. Later easing included social aspects, too. But even the opening for tourism to Denmark was effectuated because of domestic political pressure from the tourism industry, against considerable reluctance from the national government. Furthermore, a national rhetoric has dominated government statements especially in Denmark, warlike by naming COVID-19 the country's worst crisis since the traumatic German occupation in WW II, talking about Danes and crisis and foreign threat. Especially Sweden's more relaxed approach to fighting the pandemic was antagonized rhetorically. When the Danish prime minister presented her government's original four phase plan to reopen Danish society in April shortly after Easter, opening the borders was not even on the agenda of phase four. Cross-border cooperation within Euroregion Sønderjylland-Schleswig has been set on standby mode. Cross-border rescue services have been suspended, as have meetings in the three-municipality (cross-)Border Triangle. Deeper issues of built-up trust and familiarity are at stake. On the other hand, COVID-19 has demonstrated the extensive interaction on business and personal levels, as well as the density of multiple flows and social interaction across the border. It also has demonstrated stakeholders' and especially the two national minorities' ability to mobilize support and influence government decisions of easing the closure for certain people and flows. The reopening showed a rather quick return to normal. Danes shop in Flensburg again, and Germans still go on holidays in Denmark. Still, incentives to engage in cross-border cooperation will probably move away from a constructivist cross-border region approach with commitments to permanent institutional cooperation and infrastructure sharing to a more flow-oriented, border as a resource (Sohn 2014) approach. People cross the border to exploit differences to engage in profitable economic and social cooperation, as shopping, leisure travelling and work-related commuting.

\section{Notes}

1 This essay builds on the author's long-standing research on the Danish-German border region, observations during the COVID-19 lockdown and border closure, information provided by the Border Information Centre and media analysis. Observations may be biased by the author's personal experience as a cross-border commuter and transnational borderlander directly affected by the border closure.

2 Flensbook - for danskere i Flensborg (predominantly Danish citizens having moved to Flensburg), Arbeiten in Dänemark ('Work in Denmark', predominantly Germans commuting to Denmark), Einreiseverbot Dänemark ('Prohibition of Entry into Denmark', predominantly Germans affected by the border closure, many tourists) and Abn Grænsen NU ('Open the Border Now', predominantly members of the two national minorities).

\section{Works Cited}

Fink, Troels. 1979. Da Sønderjylland blev delt. 3 vols. Aabenraa: Institut for Grænseregionsforskning.

Klatt, Martin. 2020. "The So-Called 2015 Migration Crisis and Euroscepticism in Border Regions: Facing Re-Bordering Trends in the Danish-German Borderlands." Geopolitics 5(3): 567-586. https://doi.org/10.1080/14650045.2018.1557149

Sohn, Christophe. 2014. "The Border as a Resource in the Global Urban Space: A Contribution to the Cross-Border Metropolis Hypothesis." International Journal of Urban and Regional Research 38(5): 1697-1711. https://doi. org/10.1111/1468-2427.12071

Wind, Marlene. 2012. "The blind, the deaf and the dumb! How domestic politics turned the Danish Schengen controversy into a foreign policy crisis." In Danish Foreign Policy Yearbook, edited by Nanna Hvidt and Hans Mouritzen. Copenhagen: Danish Institute for International Studies. 131-156. 